Proc. Estonian Acad. Sci. Geol., 2000, 49, 2, 126-146

\title{
SILURIAN BRACHIOPODS IN THE TIMAN- NORTHERN URAL REGION: ZONATION AND PALAEOECOLOGY
}

\author{
Tatyana M. BEZNOSOVA
}

Institute of Geology, Komi Science Centre, Uralian Division of the Russian Academy of Sciences, Pervomajskaya 54, 167982 Syktyvkar, Komi Republic, Russia; Beznosova@geo.komisc.ru

Received 3 January 2000, in revised form 10 March 2000

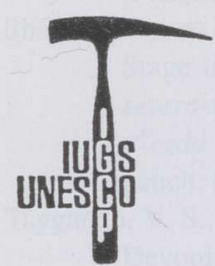

IGCP Project 406

Circum-Arctic LowerMiddle Palaeozoic

Vertebrate Palaeontology and Biostratigraphy

\begin{abstract}
In the Timan-northern Ural region, the Silurian is represented mainly by various limestones, secondary dolostones, and evaporites. The environments in the basin range from shallow-water coastal (northern Timan) and supratidal-subtidal (Pechora Syneclise, western slope of the Urals) to slope and basinal (western slope of the Urals). In the northeastern Timan and Subpolar Urals brachiopods are one of the most abundant benthic faunal groups and have great importance in local stratigraphy. Brachiopod zonation based on the distribution of pentamerids, athyrids, atrypids, spiriferids, and strophomenids includes 10 zones and allows correlation of the Silurian sequence in the Timan-northern Ural region with those in other Arctic regions of Russia, and with the Baltic area. Changes in the composition and distribution of brachiopod associations in the Timan-northern Ural region reflect highly variable ecological conditions in the basin.
\end{abstract}

Key words: brachiopods, biostratigraphy, Silurian, Timan-northern Ural region, Russia.

\section{INTRODUETION}

Lower Palaeozoic rocks are widespread in the Timan-northern Ural region. Systematic studies of the Silurian strata in this region were started by A. I. Pershina. The first stratigraphical scheme of the region was based on the brachiopod zonation worked out by Pershina (Brejvel' et al. 1980), and the brachiopods collected by A. I. Pershina were later restudied by the author. The study of the taxonomy, distribution, and zonation of the upper Silurian 
brachiopods was started by T. L. Modzalevskaya who described several collections from sections on the Kozhym, Synya, and Padimejtyvis rivers (Modzalevskaya 1974, 1980a, 1985). Recently, based on the distribution of brachiopods and their geochemistry, it has been concluded that the lower part of the Belush'ya Stage, previously correlated with the Prridoli (Antsygin et al. 1993), is of Ludfordian age (Modzalevskaya \& Wenzel 1999).

The stratigraphy of the Ordovician and Silurian sediments on the western slope of the Ural Mountains, the Northern, Subpolar, and Polar Urals; Paj-Khoj, Chernov, and Chernyshev uplifts; and the northern Timan (Fig. 1), published in the latest version of the Unified Stratigraphical Scheme of the Urals (Antsygin et al. 1993), is largely based on the distribution of brachiopods (for summary see Beznosova 1994). New data collected by the author permits higher precision in the subdivision of the upper Ordovician and Silurian strata but also identifies more precisely the position of the Ordovician-Silurian boundary in the region. Pershina (1971) mistakenly correlated the uppermost Ordovician strata (Kos'yu and Adak stages) with the Silurian. Specific brachiopod faunas dominated by pentamerids occur in the Filipp"el' (late Aeronian or early Telychian) and Padimejtyvis-Sizim (Ludlow) reefs, and for reefal deposits of these strata new zones, the Pseudoconchidium kozhimicum-Virgianella vaigatschensis Zone and the Conchidium novosemelicum Zone respectively, are described.

Illustrated specimens are housed in the type collection in the Institute of Geology, Komi Science Centre, Uralian Division of the Russian Academy of Sciences, Syktyvkar.

Fig. 1. Generalized structural map of the Timan-northern Ural region. The patterned square indicates the type area of the regional Ordovician-Silurian stratigraphical units in the Kozhym River basin, Subpolar Urals. 1, Padimejtyvis River and Bezymyannyj Brook; 2, Adak, Shar'yu, and Usa rivers; 3, Kharuta, Povarnitsa, and Fomayu rivers; 4, Kozhym and Bet'yu rivers; 5, Shchugor River; 6, Ilych River; 7, Un'ya River; 8, Chernaya River.

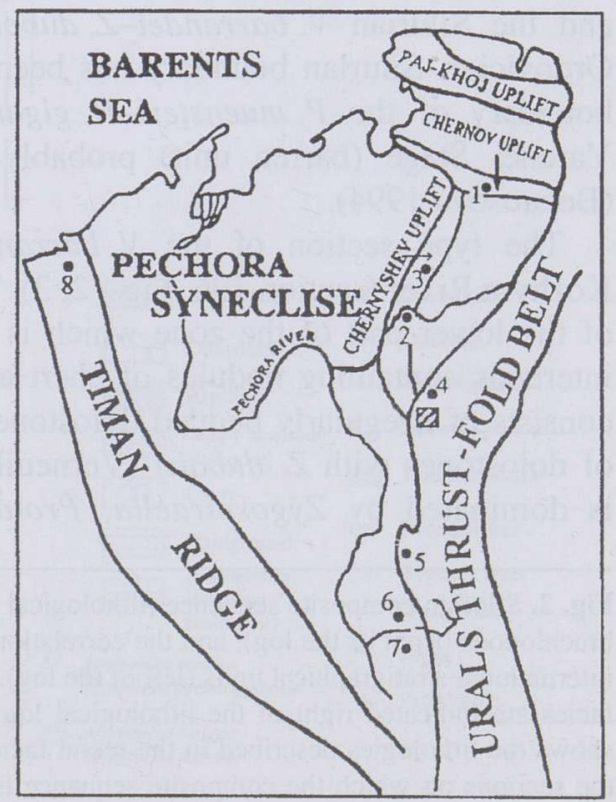




\section{BRACHIOPOD ZONATION}

Virgiana barrandei-Zygospiraella duboisi Zone. For many years, the brachiopod zone corresponding to the lowest Llandovery in the north of the Urals was called the Virgiana barrandei-Stricklandia lens Zone although the diagnostic species Stricklandia lens (Sowerby) has never been found in this region. Therefore, the zonal name $V$. barrandei-S. lens was not appropriate for this interval and was replaced by V. barrandei-Z. duboisi (Beznosova 1989a, 1989b). Both of these taxa occur in the Silurian sequence of the Timan-northern Ural region (Fig. 2). The lower boundary of the zone is defined by the appearance of $V$. barrandei (Billings) (Pl. I, fig. 1) and the upper by the appearance of Pentamerus aff. oblongus Sowerby (PI. I, figs. 5, 10). Characteristic of this zone are also Virgiana adakia Pershina \& Beznosova (Pl. I, figs. 2, 3), and the taxa Nalivkinia costulata Beznosova (Pl. I, fig. 4), Pseudocamarotoechia(?) usaensis Beznosova (Pl. I, figs. 6, 7), and Idiospira menneri Beznosova (Pl. I, fig. 9), appearing already in the upper Ashgill. The V. barrandei-Z. duboisi Zone corresponds to the main part (excluding the lowermost strata, $30-50 \mathrm{~m}$ in thickness; so-called barren unit) of the Yarenej Stage (Fig. 2). An early to middle Llandovery age (Rhuddanian and lowermost Aeronian?) for the V. barrandei$Z$. duboisi Zone is based on the occurrence of the zonal species of brachiopods and the tabulates Palaeofavosites alveolaris (Goldfuss), Catenipora gothlandica Yabe, the rugose coral Dalmanophyllum dalmani (Milne-Edwards \& Haime), and the conodonts Pedavis vindemus Melnikov and Ozarkodina corona Melnikov. The barren unit lies between strata with the Ordovician Proconchidium muensteri-Holorhynchus giganteus Zone fauna (late Ashgill; Pl. I, fig. 1) below and the Silurian V. barrandei-Z. duboisi Zone fauna above (Fig. 2). As the Ordovician-Silurian boundary has been provisionally correlated with the upper boundary of the P. muensteri-H. giganteus Zone, the lowermost part of the Yarenej Stage (barren unit) probably corresponds to the lower Llandovery (Beznosova 1994).

The type section of the V. barrandei-Z. duboisi Zone is located on the Kozhym River (section 196, Figs. 2, 3). The Virgiana community is characteristic of the lower part of the zone which is represented by massive dolostones with interbeds containing nodules of chert and breccias. The upper part of the zone consists of irregularly bedded dolostones with numerous burrows, and interbeds of dolostones with Z. duboisi (Verneuil). The zonal assemblage of brachiopods is dominated by Zygospiraella, Protatrypa, and "Nalivkinia". V. barrandei

Fig. 2. Silurian composite sequence (lithological log) of the Subpolar Urals, distribution of selected brachiopods (right of the $\log$ ), and the correlation of brachiopod zones and regional stages with the international stratigraphical units (left of the $\log$ ). The brachiopod zones identified only in the reefal facies are indicated right of the lithological $\log$ (in these intervals the right-hand part of the log shows the lithologies described in the reefal facies). Above the lithological log are the numbers of the sections on which the composite sequence is based (for geographic location of these sections refer to Fig. 3). Data on reefal facies come from the sections on the Un'ya and Ilych rivers. 


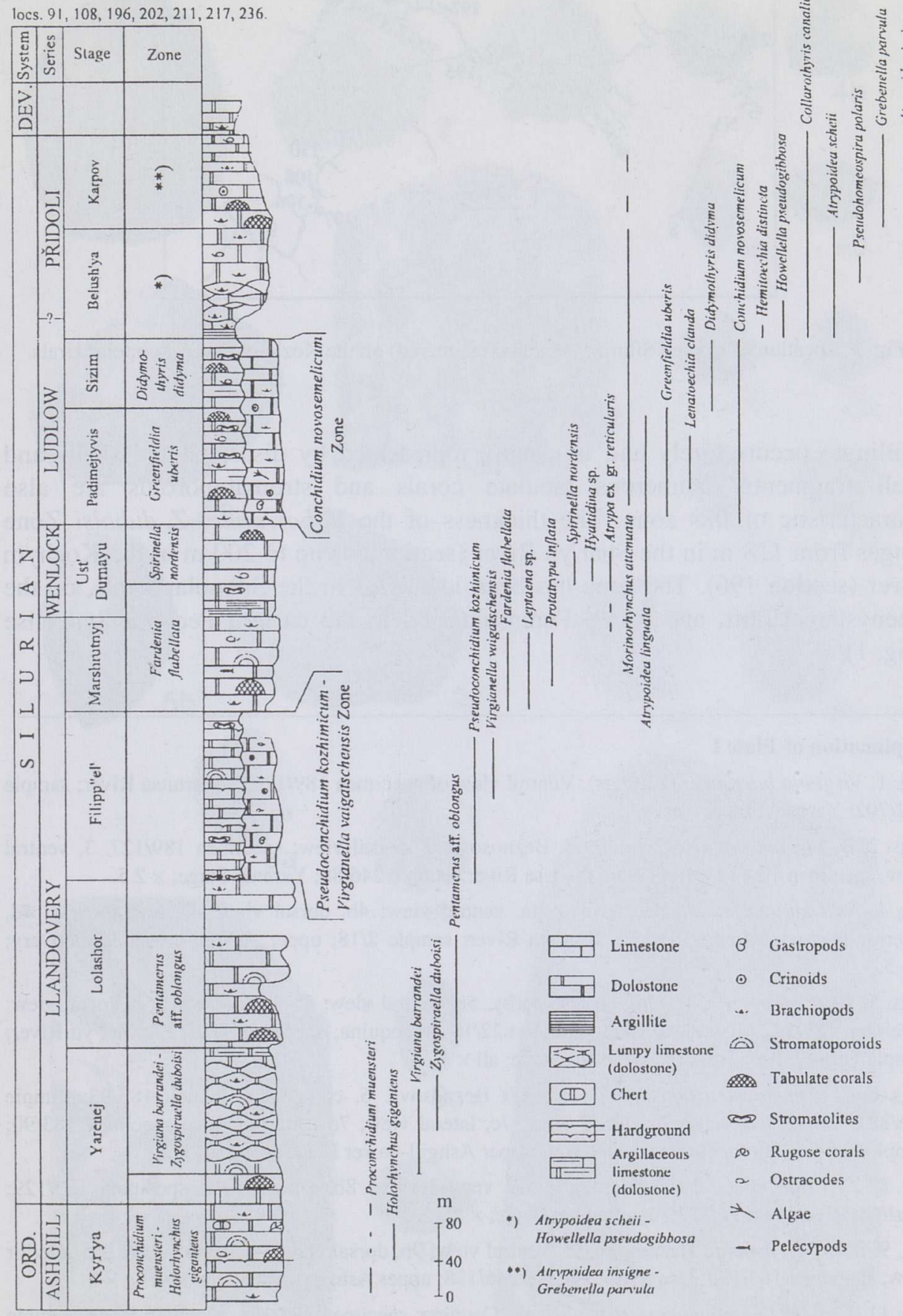




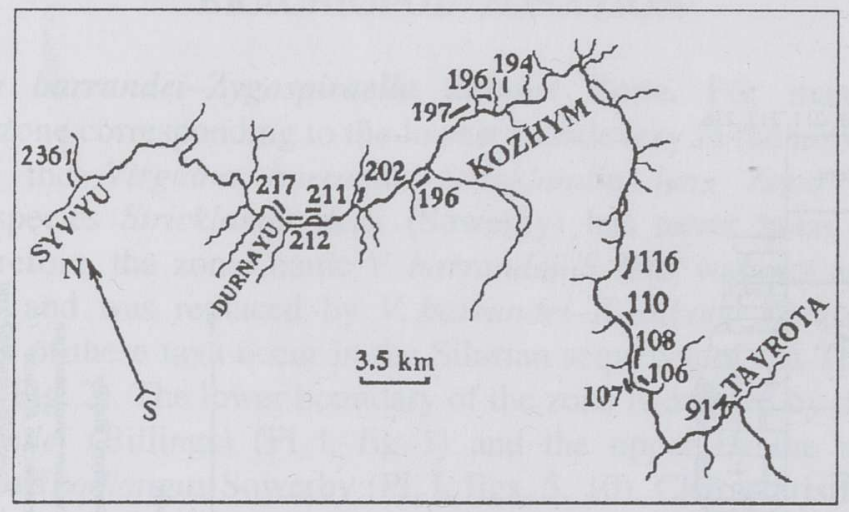

Fig. 3. Location of studied Silurian sections (numbered) on the Kozhym River, Subpolar Urals.

(Billings) occurs rarely and is usually represented by disarticulated shells and shell fragments. Numerous tabulate corals and stromatoporoids are also characteristic of this zone. The thickness of the V. barrandei-Z. duboisi Zone ranges from $118 \mathrm{~m}$ in the Shar'yu River (section 64) up to $200 \mathrm{~m}$ in the Kozhym River (section 196). The zone has been identified in the Subpolar Urals, on the Chenyshev Uplift, and Kanin Peninsula, and in the eastern Pechora Syneclise (Fig. 1).

\section{Explanation of Plate I}

Fig. 1. Virgiana barrandei (Billings). Ventral view of specimen 189/126; Povarnitsa River; sample 192/702; Yarenej Stage; $\times 1$.

Figs. 2, 3. Virgiana adakia Pershina \& Beznosova. 2, dorsal view; specimen 189/127. 3, ventral view, specimen 189/128. Both from the Usa River; sample 246/88; Yarenej Stage; $\times 2.5$.

Fig. 4. Nalivkinia costulata Beznosova. 4a, ventral view; 4b, dorsal view; 4c, lateral view; 4d, anterior view; specimen 183/153; Kharuta River; sample 2/18; upper Ashgill-lower Llandovery; $\times 2.5$.

Figs. 5, 10. Pentamerus aff. oblongus Sowerby. 5a, ventral view; 5b, lateral view; 5c, dorsal view; specimen 189/122; Chernaya River; sample 622/1. 10, coquina; specimen 189/129. Shar'yu River; sample 68/549. Both from the Lolashor Stage; all $\times 1$.

Figs. 6, 7. Pseudocamarotoechia(?) usaensis Beznosova. 6, coquina; specimen 183/93; sample 246/881. 7a, ventral view; 7b, dorsal view; 7c, lateral view; 7d, anterior view; specimen 183/90; sample 246/361. Both from the Usa River; upper Ashgill-lower Llandovery; all $\times 2$.

Fig. 8. Zygospiraella duboisi (Verneuil). 8a, ventral view; 8b, dorsal view; specimen 183/129; Kozhym River; sample 217/361; Yarenej Stage; $\times 2$.

Fig. 9. Idiospira menneri Beznosova. 9a, ventral view; 9b, dorsal view; 9c, lateral view; 9d, anterior view; specimen 183/129; Usa River; sample 246/178; upper Ashgill-lower Llandovery; $\times 2$.

Fig. 11. Proconchidium muensteri St. Joseph. Coquina; specimen 183/118; Kozhym River; sample 108/2; upper Ashgill; $\times 1$. 
PLATE I
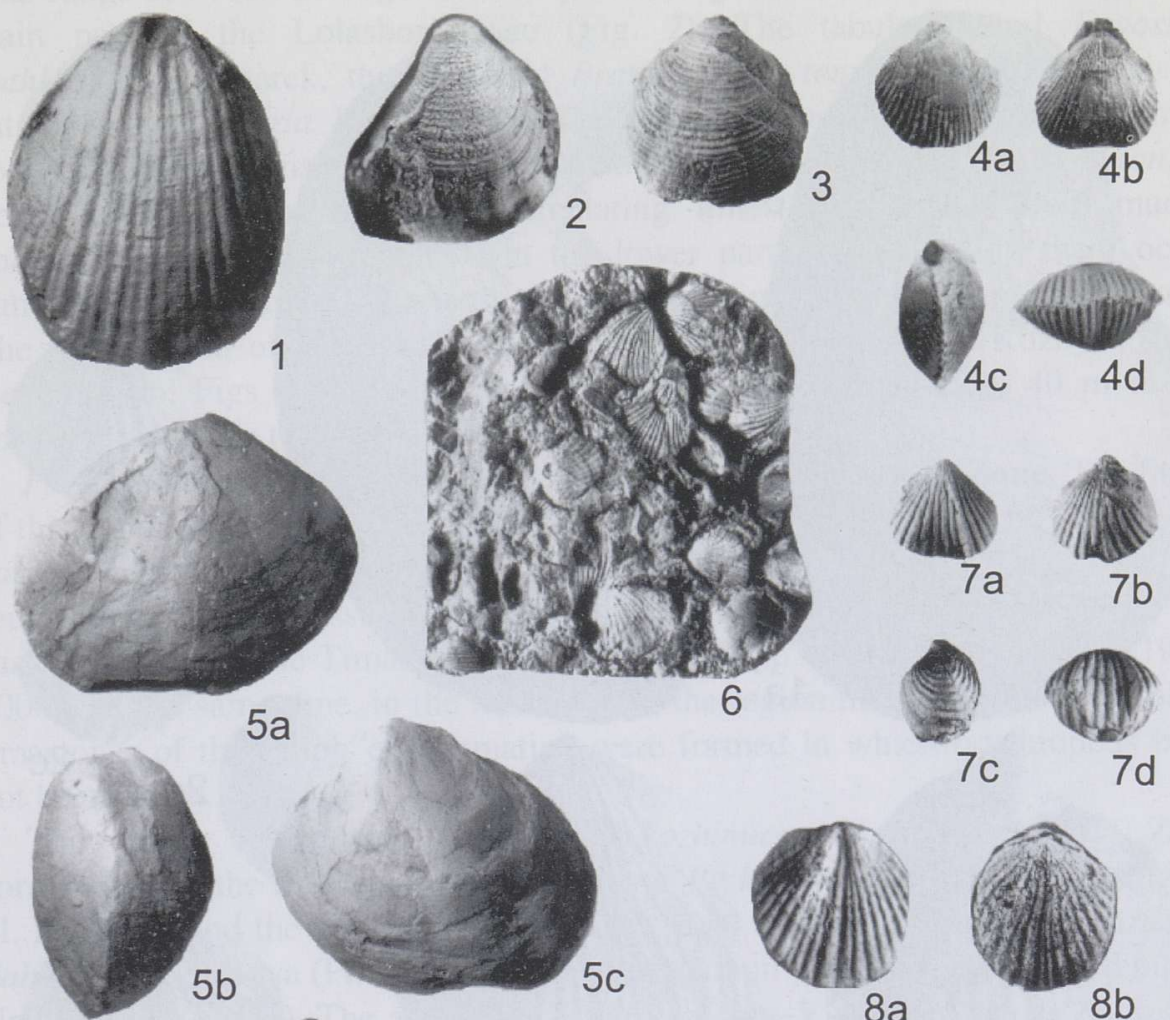

$5 a$

$5 b$

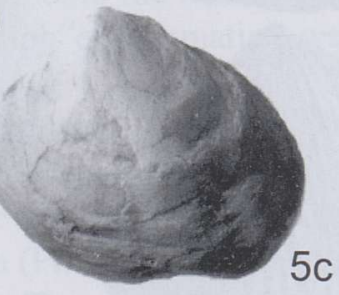

6
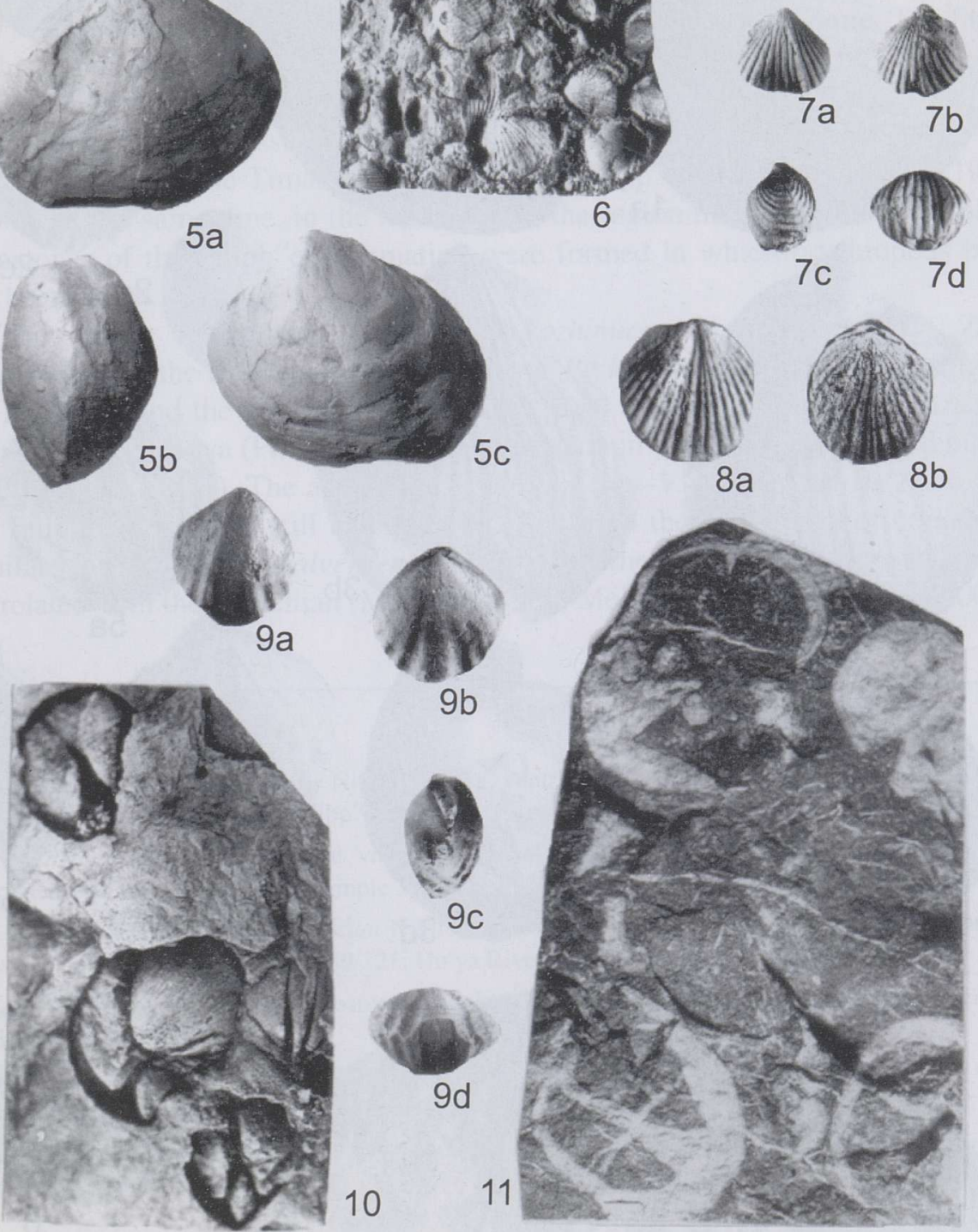

$8 b$ 

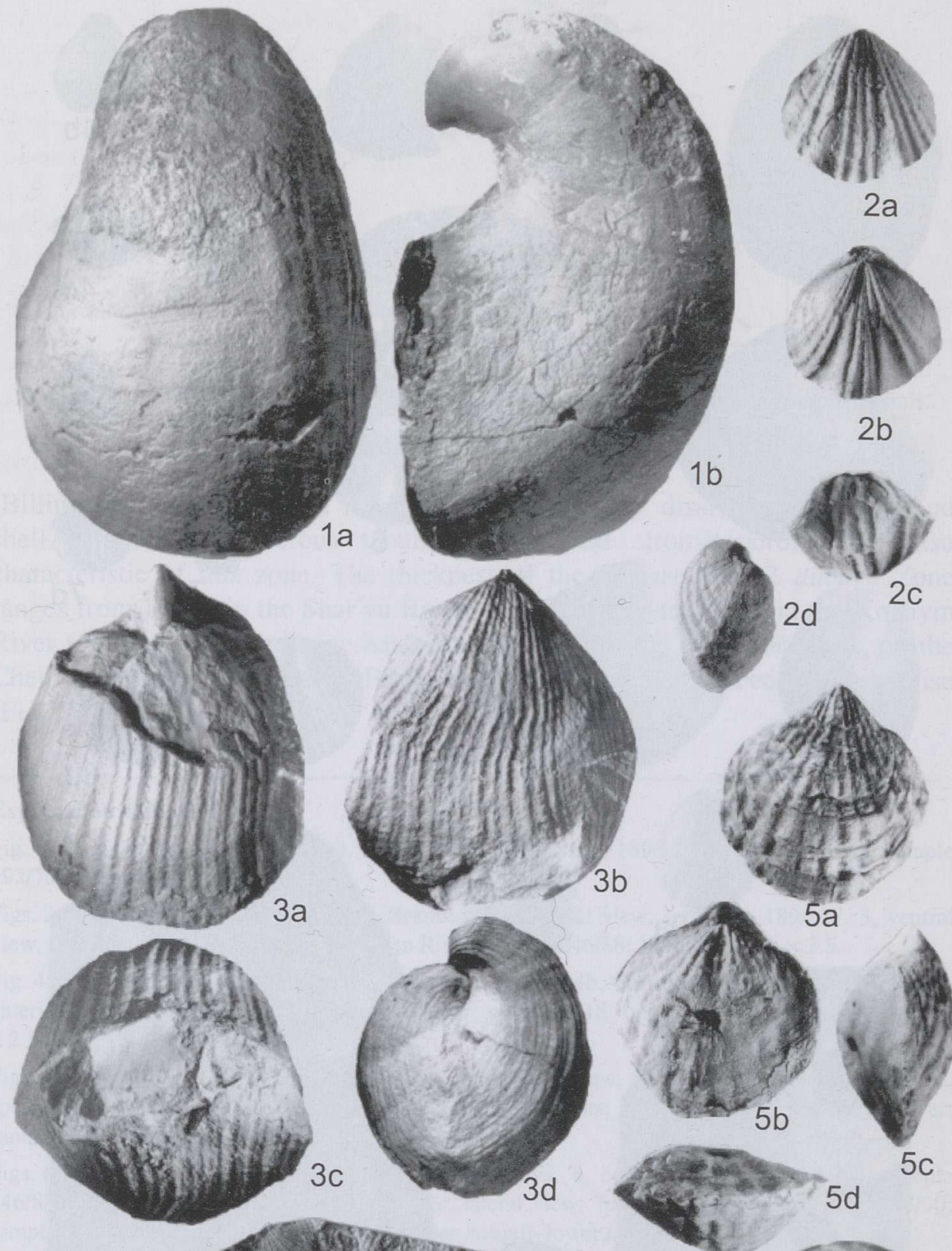
Pentamerus aff. oblongus Zone. This zone corresponds to the interval of the total range of $P$. aff. oblongus Sowerby (Pl. I, figs. 5, 10) and correlates with the main part of the Lolashor Stage (Fig. 2). The tabulate coral Favosites gothlandicus Lamarck, the conodont Pranognathus tenuis (Aldridge), and the ostracodes Hisingeria hisingeri (Schmidt) and Hogmochilina maakii Schmidt correlate it approximately with the Aeronian. The strata of the $P$. aff. oblongus Zone consist of rhythmically intercalating limestones and mottled, muddy dolostones with lenses of chert. In the lower part of these strata there occur numerous tabulate corals, but in the upper half mainly stromatoporoids are found. The type section of the $P$. aff. oblongus Zone is located on the Kozhym River (section 196, Figs. 2, 3). The thickness of the zone ranges from $40 \mathrm{~m}$ in the northern Timan up to $265 \mathrm{~m}$ in the Subpolar Urals.

Pseudoconchidium kozhimicum-Virgianella vaigatschensis Zone. The fauna of this zone (Pseudoconchidium kozhimicum Nikiforova, Pl. II, fig. 3; Virgianella vaigatschensis Nikiforova, Pl. II, fig. 1; Plectatrypa sp., Pl. II, fig. 2, etc.) is found only in the massive light-coloured reefal dolostones formed along the eastern margin of the Timan-Pechora plate in Filipp"el' time (Antoshkina 1994, 2000). At the same time, in the main part of the region thin-bedded stromatolitic limestones of the Filipp"el' Formation were formed in which brachiopods have not been found.

The lower boundary of the P. kozhimicum-V. vaigatschensis Zone corresponds to the level of the appearance of $P$. kozhimicum Nikiforova (Fig. 2; Pl. II, fig. 3) and the upper boundary to the level of the appearance of Fardenia flabellata Beznosova (PI. II, fig. 4). The type section of this zone is located on the Un'ya River (Fig. 1). The age of the P. kozhimicum-V. vaigatschensis Zone, and the Filipp"el' Stage, is still uncertain but, based on the occurrence of conodonts similar to Icriodella malvernensis Aldridge, these strata are provisionally correlated with the Telychian (Melnikov 1984; Melnikov \& Zhemchugova 2000).

\section{Explanation of Plate II}

Fig. 1. Virgianella vaigatschensis Nikiforova. 1a, ventral view; 1b, lateral view; specimen 189/92; Un'ya River; sample 37/2821; Filipp"el' Stage; $\times 1$.

Fig. 2. Plectatrypa sp. 2a, ventral view; $2 \mathrm{~b}$, dorsal view; $2 \mathrm{c}$, anterior view; $2 \mathrm{~d}$, lateral view; specimen 189/100; Un'ya River; sample 37/2823; Filipp"el' Stage; $\times 1.5$.

Fig. 3. Pseudoconchidium kozhimicum Nikiforova. 3a, ventral view; $3 \mathrm{~b}$, dorsal view; $3 \mathrm{c}$, anterior view; 3d, lateral view; specimen 189/121; Un'ya River; sample 37/2822; Filipp"el' Stage; $\times 1$.

Fig. 4. Fardenia flabellata Beznosova. Coquina; specimen 183/106; Shchugor River; sample 10/146; Marshrutnyj Stage; $\times 1$.

Fig. 5. Atrypa ex gr. reticularis (Linnaeus). 5a, ventral view; $5 b$, dorsal view; $5 c$, lateral view; 5d, anterior view; specimen 190/66; Kozhym River; sample 202/84; Marshrutnyj Stage; $\times 2.5$.

Fig. 6. Leptaena? sp. Ventral view of specimen 190/85; Shar'yu River; sample 64/5; Marshrutnyj Stage; $\times 2.5$. 
The P. kozhimicum-V. vaigatschensis Zone has been recognized in the Subpolar Urals where its thickness reaches up to $100 \mathrm{~m}$. In the Polar Urals, reefal structures with Harpidium angustum Poulsen have been described and are also considered to correspond to the P. kozhimicum-V.vaigatschensis Zone (Sapelnikov \& Beznosova 1980; Antoshkina 1994).

Fardenia flabellata Zone. The lower boundary of this zone is marked by the first appearance of $F$. flabellata Beznosova (Pl. II, fig. 4), and the zone is recognized in the Subpolar Urals and the Chernyshev Uplift. In the type section on the Kozhym River (near the mouth of the Marshrutnyj Creek; section 202, Figs. 2, 3), the strata corresponding to this zone are represented by an intercalation of thick-bedded dolostones with shelly faunas, and of massive limestones and dolostones rich in corals and stromatoporoids. Besides Fardenia flabellata Beznosova, Protatrypa inflata Beznosova (PI. III, fig. 1) and Leptaena?

\section{Explanation of Plate III}

Fig. 1. Protatrypa inflata Beznosova. 1a,b, ventral view; 1c, dorsal view; 1d, lateral view; 1e, anterior view; specimen 183/105; Shar'yu River; sample 64/82; Marshrutnyj Stage; 1a $\times 1$, 1b-e $\times 2$.

Fig. 2. Atrypoidea linguata (Buch). $2 \mathrm{a}$, dorsal view; $2 \mathrm{~b}$, lateral view; $2 \mathrm{c}$, anterior view; specimen 190/86; Bezymyannyj Brook; sample 2/412; Marshrutnyj Stage; $\times 1.5$.

Figs. 3, 4. Spirinella nordensis (Ljashenko). 3a, ventral view; 3b, dorsal view; $3 \mathrm{c}$, anterior view; 3d, lateral view; specimen 183/163; Bezymyannyj Brook; sample 2/412; Ust'Durnayu Stage; $\times 2$. 4, detail of sculpture; specimen 183/168; Bezymyannyj Brook; sample 2/412a; Ust'Durnayu Stage; $\times 5$.

Fig. 5. Conchidium novosemelicum Nalivkin. Ventral view of specimen 183/130; Ilych River; sample 37/251; Ludlow; $\times 1$.

Fig. 6. Conchidium biloculare asiaticum Sapelnikov. Ventral view of specimen 189/130; Ilych River; sample 109/384; Ludlow; × 1.

Fig. 7. Lenatoechia clauda Modzalevskaya. 7a,b, ventral view; 7c, dorsal view; 7d, lateral view; 7e, anterior view; specimen 183/127; Kozhym River; sample 211/163; Padimejtyvis Stage; $7 \mathrm{a} \times 1$, $7 \mathrm{~b}-\mathrm{e} \times 2.5$.

Fig. 8. Hyattidina $\mathrm{sp}$. $8 \mathrm{a}$, ventral view; $8 \mathrm{~b}$, dorsal view; $8 \mathrm{c}$, anterior view; $8 \mathrm{~d}$, lateral view; specimen 183/144; Bezymyannyj Brook; sample 2/414; Ust'Durnayu Stage; $\times 1$.

Fig. 9. Morinorhynchus cf. attenuata (Amsden). Ventral view of specimen 183/164; Kozhym River; sample 236/107; Ludlow-Přidoli; $\times 2.5$.

Fig. 10. Eoreticularia annae Beznosova. 10a, ventral view; 10b, dorsal view; 10c, lateral view; 10d, anterior view; specimen 183/32; Padimejtyvis River; sample 1/114; Padimejtyvis Stage; $\times 2$.

Fig. 11. Glassina dissecta Modzalevskaya. Coquina; specimen 183/52; Padimejtyvis River; sample 1/72; Padimejtyvis Stage; $\times 2$.

Fig. 12. Didymothyris didyma (Dalman). 12a, ventral view; 12b, dorsal view; 12c, lateral view; 12d, anterior view; specimen 183/165; Kozhym River; sample 236/176; Sizim Stage; $\times 2$.

Fig. 13. Greenfieldia uberis Modzalevskaya. 13a, ventral view; 13b, dorsal view; 13c, lateral view; 13d, anterior view; specimen 183/75; Padimejtyvis River; sample 1/59; Padimejtyvis Stage; $\times 1.5$. 
PLATE III

19

(8)

(f) $1 \mathrm{~b}$
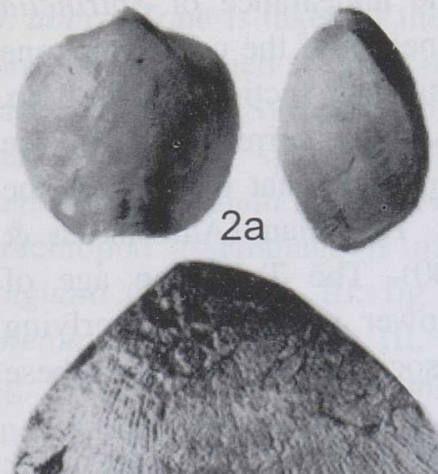

1
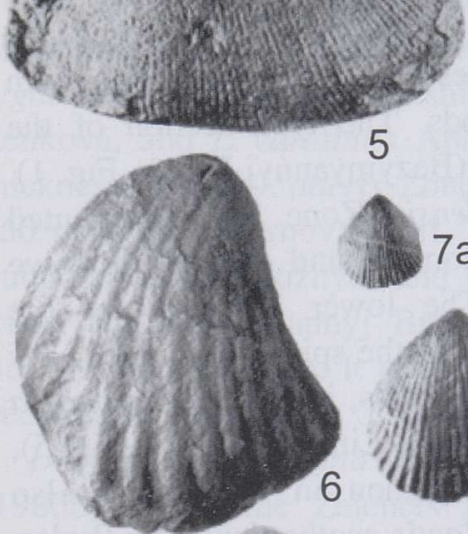

5
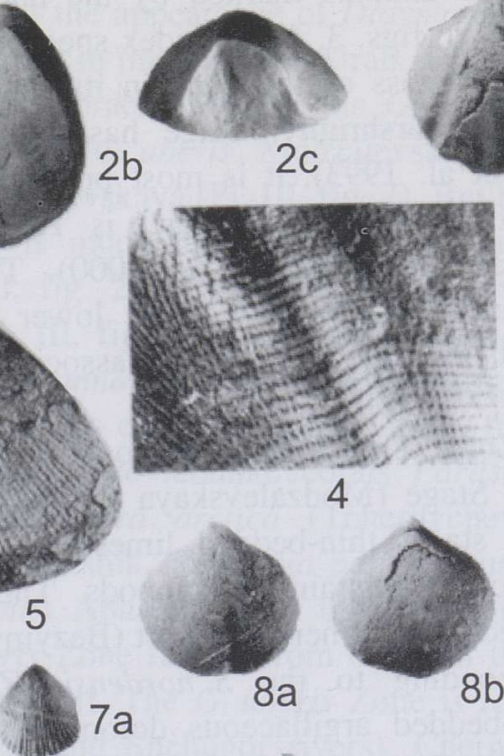

4
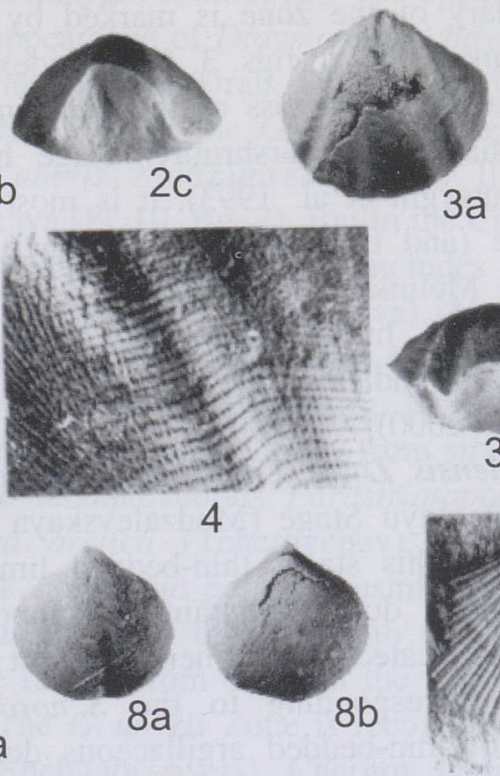

$3 a$
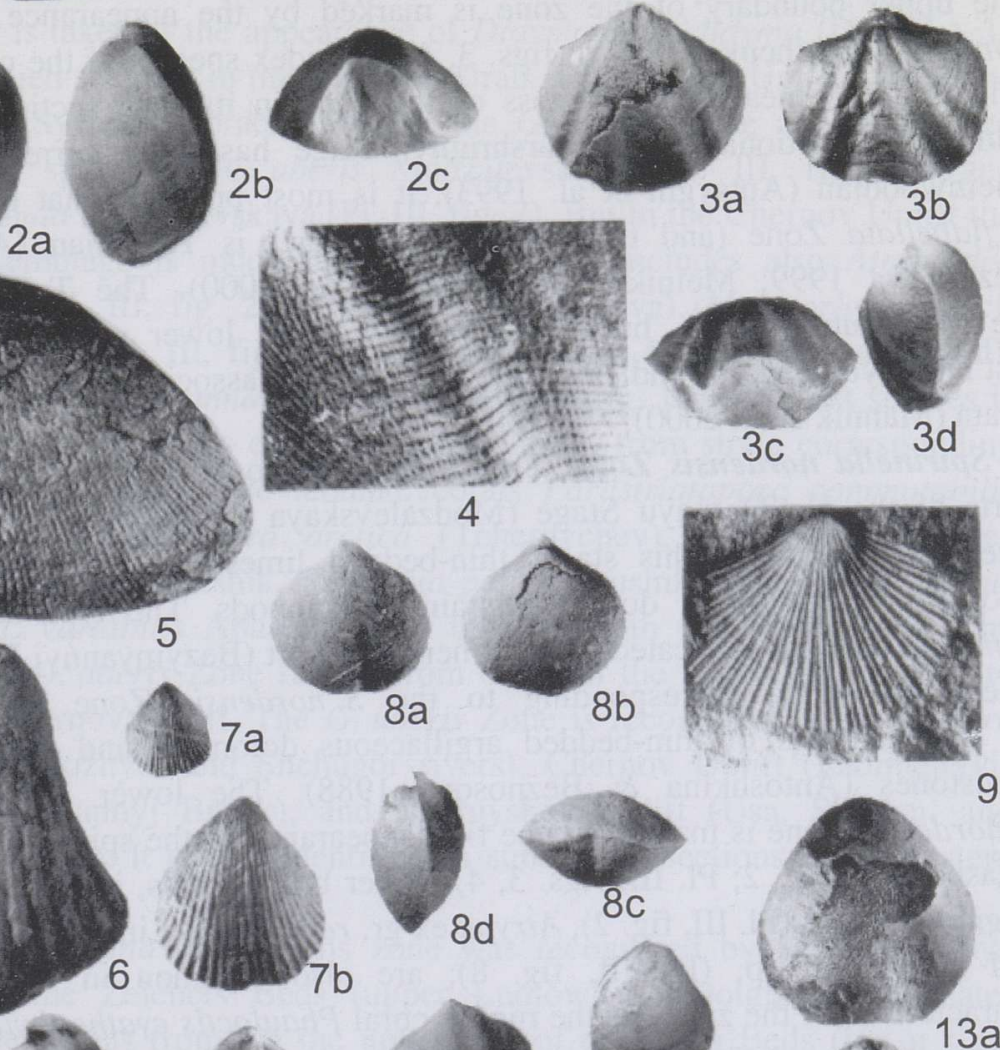

(ifini) 4
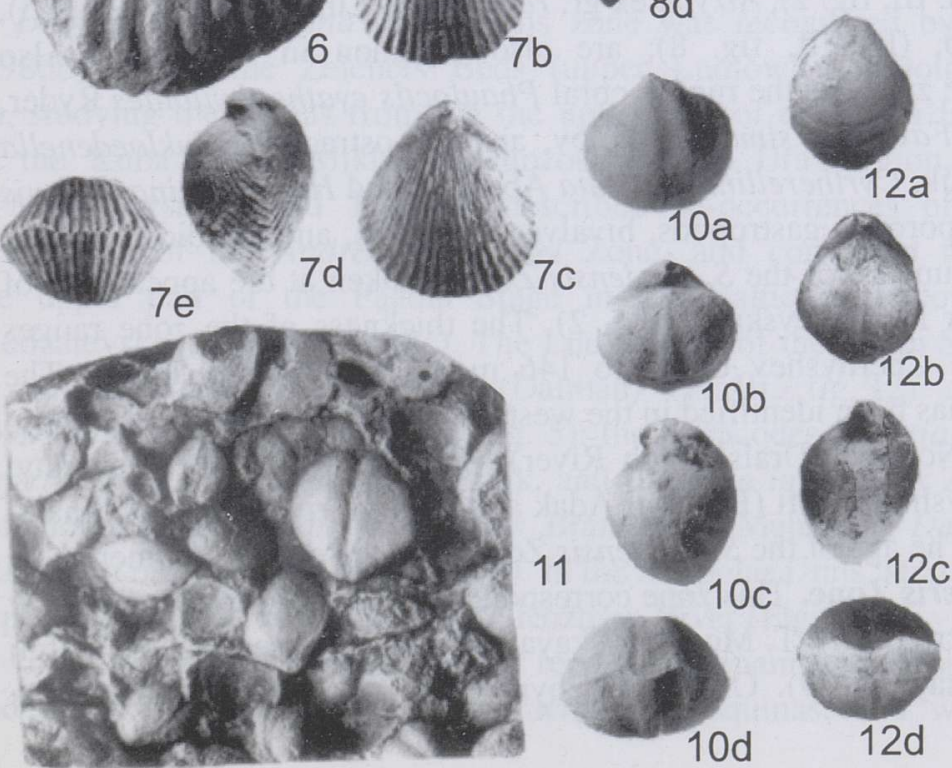
sp. (Pl. II, fig. 6) are common in this zone. Corals and stromatoporoids are usually abundant and form much of the rock. In the Subpolar Urals and the Chernyshev Uplift, the brachiopods are associated with the ostracode Herrmannina insignis Abushik. The lower boundary of the $F$. flabellata Zone is defined by the appearance of the index species and coincides with the boundary between the Filipp"el' and Marshrutnyj stages (Tsyganko \& Chermnykh 1987). The upper boundary of the zone is marked by the appearance of Spirinella nordensis (Ljashenko) (Pl. III, figs. 3, 4), an index species of the overlying zone (Fig. 2). The measured thickness of the zone in its type section is $114.5 \mathrm{~m}$. Although traditionally the Marshrutnyj Stage has been correlated with the Sheinwoodian (Antsygin et al. 1993), it is most probable that the age of the F. flabellata Zone (and the Marshrutnyj Stage) is Telychian (Antoshkina \& Beznosova 1999; Melnikov \& Zhemchugova 2000). The Telychian age of the Marshrutnyj Stage, but probably also of the lower part of the overlying Ust'Durnayu Stage, is indicated by the conodont association occurring in these strata (Männik et al. 2000).

Spirinella nordensis Zone. This zone corresponds to the middle and upper parts of the Ust'Durnayu Stage (Modzalevskaya \& Beznosova 1992; Fig. 3). The lower strata of this stage, thin-bedded limestones and dolostones with stromatolitic interbeds, do not contain brachiopods. The type section of the S. nordensis Zone is located on the Chernov Uplift (Bezymyannyj Brook, Fig. 1). There the strata corresponding to the S.nordensis. Zone are represented by intercalations of thin-bedded argillaceous dolomitic and mottled massive limestones (Antoshkina \& Beznosova 1988). The lower boundary of the S. nordensis Zone is marked by the first appearance of the spiriferid S. nordensis (Ljashenko) (Fig. 2; Pl. III, figs. 3, 4). Other brachiopods, including Atrypoidea linguata (Buch) (Pl. III, fig. 2), Atrypa ex gr. reticularis (Linnaeus) (Pl. II, fig. 5), and Hyattidina sp. (PI. III, fig. 8), are also common in this zone. Also characteristic of the zone are the rugose coral Phaulactis cyathophylloides Ryder, the tabulate coral Favosites similis Sokolov, and the ostracodes Eukloedenella grandifabae Abushik, Cyrtherellina inornata Abushik, and Herrmannina insignis Abushik. Stromatoporoids, gastropods, bivalves, trilobites, and crinoids occur as well. The upper boundary of the $S$. nordensis Zone is taken at the appearance of Greenfieldia uberis Modzalevskaya (Fig. 2). The thickness of the zone ranges from $60 \mathrm{~m}$ on the Chernyshev Uplift to $146 \mathrm{~m}$ on the Chernov Uplift. The S. nordensis Zone has been identified in the western Subpolar Urals (Kozhym and Shchugor rivers), Northern Urals (Ilych River), Chernov Uplift (Bezymyannyj Brook), and Chernyshev Uplift (Bol'shoj Adak and Shar'yu rivers; Antoshkina \& Beznosova 1999). The age of the S. nordensis Zone is late Wenlock (Homerian).

Greenfieldia uberis Zone. This zone corresponds to the Padimejtyvis Stage. It was originally described by T. Modzalevskaya with its type section on Dolgij Island (Modzalevskaya 1979). On the Kozhym River, the strata of this zone 
consist of limestones and dolostones with interbeds of stromatoporoid-coral, ostracode, and nodular limestones (Tsyganko \& Chermnykh 1983; Beznosova 1994). The lower boundary of the zone (the level of the appearance of G. uberis) in the Kozhym River sequence corresponds to the boundary between the Ust'Durnayu and Padimejtyvis stages ( $=$ the Wenlock-Ludlow boundary; Antoshkina \& Beznosova 1988; Antsygin et al. 1993). The upper boundary of the G. uberis Zone is taken at the appearance of Didymothyris didyma (Dalman). In most of the studied sections in the Subpolar Urals, Chernyshev Uplift, and in the eastern Pechora Syneclise, brachiopods in the G. uberis Zone are represented mainly by two species - G. uberis Modzalevskaya (Pl. III, fig. 13) and Lenatoechia clauda Modzalevskaya (Pl. III, fig. 7). But in the Chernov Uplift the brachiopod assemblage is much more variable and includes also Atrypoidea linguata (Buch) (Pl. III, fig. 2), A. modesta (Nikiforova), Morinorhynchus cf. attenuata (Amsden) (Pl. III, fig. 9), Glassina dissecta Modzalevskaya (Pl. III, fig. 11), and Eoreticularia annae Beznosova (Pl. III, fig. 10). The last species is known only from the sections on the Chernov Uplift, from strata corresponding to the Padimejtyvis Stage. The tabulate corals Parastriatopora commutabilis Klaamann and Parastriatopora arctica (Tchernychev), and the ostracodes Signetopsis bicardinata Abushik, Beyrichia parva Abushik, Leiocyamus paulus Zenkova, and $L$. variabilis Abushik occur together with the brachiopods. The thickness of the G. uberis Zone ranges from $60 \mathrm{~m}$ in the Subpolar Urals up to $150 \mathrm{~m}$ on the Chernov Uplift. The G. uberis Zone is recognized in the western Subpolar Urals (Kozhym and Shchugor rivers), Chernov Uplift (Padimejtyvis River and Bezymyannyj Brook), and Chernyshev Uplift (Usa, Shar'yu, and Bol'shoj Adak rivers). It is also identified in subsurface sections in the eastern Pechora Syneclise.

Didymothyris didyma Zone. This zone was recognized by Modzalevskaya (1980b) within the Zelenets Beds (upper Ludlow) on Dolgij Island. Later on, studying the faunas from the the upper part of the Kuba Beds (lower flow of the Kuba River, Mikhailov subzone of the Ufa Region, Central Urals), T. Modzalevskaya and T. Märss described co-occurrences of D. didyma and vertebrates of the Andreolepis hedei Zone, and correlated these strata with the upper part of the Paadla Stage in the Baltic area (lower Ludfordian; Modzalevskaya \& Märss 1991). The Ludlow age of the Sizim Stage is indicated by the brachiopods D. didyma (Dalman) (Pl. III, fig. 12) and Conchidium novosemelicum Nalivkin (Pl. III, fig. 5); the ostracodes Kiaeria crassa Abushik, Leperditia quinqueangulata Abushik, and Bingeria infrequens Zenkova; and the conodonts Polygnathoides siluricus Branson \& Mehl and Dentacodina dubia (Rhodes) (Beznosova 1989a, 1989b). In the Subpolar Urals, strata of this zone are exposed and studied in section 236, Kozhym River (Figs. 2, 3).

Lithologically, the Sizim Stage is represented mainly by laminated limestones and dolostones alternating with brachiopod coquinas, and with stromatolitic 
limestones. Characteristic of this stage, and also of the underlying Padimejtyvis Stage, is the occurrence of reefal carbonates in some regions (see below). The assemblage of brachiopods in the laminated strata consists of D. didyma (Dalman), Morinorhynchus cf. attenuata (Amsden), Conchidium novosemelicum Nalivkin, and Atrypoidea linguata (Buch). The stage also contains tabulate corals, e.g. Thecia swinderniana (Goldfuss), Laceripora cribrosa Eichwald, and Parastriatopora spinosa Tchernychev; and the ostracodes Kieria crassa Abushik, Leiocyamus variabilis Abushik, L. clausus Abushik, and L. grandifabae Abushik. The brachiopods $D$. didyma, C. novosemelicum, and A. linguata are present in both reefal and laminated carbonates. The upper boundary of the $D$. didyma Zone is defined by the appearance of Atrypoidea scheii (Holtedahl) and coincides with the boundary between the Sizim and Belush'ya stages (Fig. 2). The thickness of the zone varies from $50 \mathrm{~m}$ (Chernyshev Uplift) to $145 \mathrm{~m}$ (Chernov Uplift). The D. didyma Zone has been recognized in the Northern and Subpolar Urals, Chernyshev and Chernov uplifts, and in the eastern Pechora Syneclise.

Conchidium novosemelicum Zone. In the reefal facies, the Greenfieldia uberis and Didymothyris didyma zones cannot be identified and the strata of the same age are placed in the Conchidium novosemelicum Zone (Beznosova 1994; Fig. 2).

Reefs are widespread in the Niyayu River basin (Subpolar Urals) and along the Ilych River (Northern Urals) (Fig. 1). The lithologies here are dominated by light grey massive limestones and dolostones rich in large-shelled brachiopods, tabulate and rugose corals, crinoids, and stromatoporoids. The brachiopods are mainly pentamerids, e.g. Conchidium novosemelicum Nalivkin, C. biloculare asiaticum Sapelnikov (Pl. III, fig. 6), C. knighti vogulicum (Verneuil), Brooksina conjugula Khodalevich, B. aff. streisi Sapelnikov, Vagranella sp., D. didyma (Dalman), Atrypoidea linguata (Buch), and Atrypa ex gr. reticularis (Linnaeus).

The C.novosemelicum Zone corresponds to the total range of the zonal brachiopod. In studied sections, its lower boundary coincides with the contact between the reefal and underlying strata. The upper boundary of the C. novosemelicum Zone is established only in the Ilych River section, where it corresponds to the base of an overlying limestone unit which yields rugose corals characteristic of the Greben' Series. In the Niyayu River basin, the position of this boundary is still problematic. The thickness of the reef complex, and the C. novosemelicum Zone, reaches up to $360 \mathrm{~m}$.

For the higher part of the Silurian sequence, corresponding to the Belush'ya and Karpov stages, two possible brachiopod zonations are proposed. One of them is based on the evolutionary lineage of Collarothyris canaliculata (Wenjukow) (Antsygin et al. 1993; Modzalevskaya \& Wenzel 1999), and the other on assemblages of different brachiopods. The Collarothyris canaliculata Zone, and its subzones C. canaliculata canaliculata, C. c. trapezoideus, C. c. lata, described by T. Modzalevskaya in the sections on Dolgij, Vajgach, and Novaya Zemlya 
islands, and also from some sections in the Timan-northern Ural region, are of great stratigraphical importance (Modzalevskaya 1980b; Antsygin et al. 1993; Modzalevskaya \& Wenzel 1999). However, in the majority of the sections in this paper, particularly in the Timan-northern Ural region, these subzones are complicated to identify due to the lack or very poor preservation of the characteristic taxa. Thus it seems appropriate to base the zonation in this interval on the co-occurrences of taxa. Two zones, Atrypoidea scheii-Howellella pseudogibbosa and Atrypoidea insigne-Grebenella parvula, are described. These zones have been recognized in most sections studied in the Timan-northern Ural region, but also in the adjacent areas (Dolgij, Vajgach, Novaya Zemlya, etc.), and can be successfully used to subdivide and correlate sections.

Atrypoidea scheii-Howellella pseudogibbosa Zone. This zone was originally described by Beznosova $(1989 \mathrm{a}, 1989 \mathrm{~b})$ in the Subpolar Urals where the most complete sections occur. In its type section (section 236 on the Kozhym River; Figs. 2, 3), the zone corresponds to the Belush'ya Stage and is correlated with the lower Prridoli. An early Prridoli age for these strata is established by the occurrence of the brachiopods Hemitoechia distincta Nikiforova (Pl. IV, fig. 7), Pseudohomeospira polaris Nikiforova (Pl. IV, fig. 8), and Collarothyris canaliculata (Wenjukow) (Pl. IV, fig. 12), and the ostracodes Eokloedenia bacata Abushik, Calcaribeyrichia grebeni Abushik, and Kiaeria lindstroemi (Schmidt) (Antsygin et al. 1993). H. pseudogibbosa Nikiforova (PI. IV, figs. 10, 11) is found only in the lower part of the zone (Fig. 2).

However, on the basis of the results of geochemical study $\left(\delta^{13} \mathrm{C}\right.$ and $\left.\delta^{18} \mathrm{O}\right)$ of brachiopods it has been concluded that the lower part of the Belush'ya Stage may still correspond to the Ludfordian (Modzalevskaya \& Wenzel 1999). Considering the co-occurrences of taxa, for example the occurrence of rare specimens of C. c. trapezoideus (Pl. IV, fig. 9) in the A. scheii-H. pseudogibbosa Zone, this zone most probably corresponds to the C. c. canaliculata and C. c. trapezoideus subzones of Modzalevskaya (1980b).

In general, the assemblage in the A. scheii-H. pseudogibbosa Zone is dominated by smooth-shelled brachiopods like Atrypoidea scheii (Holtedahl) (PI. IV, fig. 6), A. globa (Tchernyshew), A. vangirica Beznosova \& Mizens (PI. IV, fig. 1), and A. pentagonalis Beznosova \& Mizens (PI. IV, fig. 2). Lithologically, the strata of this zone consist of rhythmically intercalating limestones (nodular, shaly, detrital, with brachiopods and ostracodes), calcareous shales, and shales. The thickness of the zone varies from $46 \mathrm{~m}$ (Chernyshev Uplift) to $130 \mathrm{~m}$ (Chernov Uplift). The A. scheii-H. pseudogibbosa Zone has been recognized in the Northern and Subpolar Urals, Chernov and Chernyshev uplifts, and also in numerous core sections in the Pechora Syneclise.

Atrypoidea insigne-Grebenella parvula Zone. This zone was first established in the Subpolar Urals with its type section on the Kozhym River (section 236; Figs. 2, 3). It corresponds to the Karpov Stage (Beznosova 1989a, 1989b). A late 
Pridoli age of this zone is based on the occurrence here of the tabulate corals Favosites favositiformis (Holtedahl), Squameofavosites thetidis (Chekhovich), the rugose corals Micula simplex Strelnikov, Nipponophyllum tardum (Strelnikov), and of the ostracodes Signetopsis michailensis Zenkova and Eokloedenia bacata Abushik (Tsyganko \& Chermnykh 1983). The A. insigne-G. parvula Zone in the Subpolar Urals is rich in macrofossils (corals, stromatoporoids, brachiopods, bryozoans) occurring in massive, platy and shaly limestones with numerous interbeds of shales. The lower part of the A. insigne-G. parvula Zone is characterized by brachiopod-coral communities, and the upper one by brachiopod-ostracode assemblages. The upper boundary of this zone coincides with the Silurian-Devonian boundary. Above this level, the Early Devonian brachiopods Protathyris praecursor Kozlowski, Mesodouvillina costatula (Barrande), and Howellella angustiplicata Kozlowski appear. The zone has been identified in the Northern and Subpolar Urals, Chernov and Chernyshev uplifts, and in the Pechora Syneclise. The A. insigne-G. parvula Zone corresponds to the C. c. lata Subzone of Modzalevskaya (1980b).

\section{Explanation of Plate IV}

Fig. 1. Atrypoidea vangirica Beznosova \& Mizens. 1a, ventral view; 1b, lateral view; 1c, anterior view; specimen 190/34; Fomayu River; sample 37/213; Belush'ya Stage; $\times 2$.

Fig. 2. Atrypoidea pentagonalis Beznosova \& Mizens. 2a, ventral view; $2 b$, dorsal view; $2 \mathrm{c}$, lateral view; 2d, anterior view; specimen 1023/98; Bet'yu River; sample 152/123; Belush'ya Stage; $\times 2$.

Fig. 3. Atrypoidea insigne (Nikiforova). 3a, ventral view; 3b, dorsal view; 3c, lateral view; 3d, anterior view; specimen 190/47; Kozhym River; sample 236/308; Karpov Stage; $\times 1.5$.

Fig. 4. Grebenella parvula (Tshernyshew \& Yakovlew). 4a,b, ventral view; 4c, dorsal view; 4d, lateral view; 4e, anterior view; specimen 183/6; Kozhym River; sample 236/715; Karpov Stage; $4 \mathrm{a} \times 1,4 \mathrm{~b}-\mathrm{e} \times 2$.

Fig. 5. Howellella nucula (Barrande). 5a, ventral view; 5b, dorsal view; 5c, lateral view; 5d, anterior view; specimen 183/142; Kozhym River; sample 236/16; Sizim Stage; $\times 2$.

Fig. 6. Atrypoidea scheii (Holtedahl). 6a, ventral view; $6 \mathrm{~b}$, lateral view; $6 \mathrm{c}$, anterior view; specimen 190/8; Kozhym River; sample 236/39; Belush'ya Stage; $\times 1$.

Fig. 7. Hemitoechia distincta Nikiforova. 7a, ventral view; 7b, dorsal view; 7c, lateral view; 7d, anterior view; specimen 189/37; Padimejtyvis River; sample 1/351; Belush'ya Stage; $\times 2$.

Fig. 8. Pseudohomeospira polaris Nikiforova. $8 \mathrm{a}$, ventral view; $8 \mathrm{~b}$, dorsal view; $8 \mathrm{c}$, lateral view; 8d, anterior view; specimen 183/142; Kozhym River; sample 236/144; Belush'ya Stage; $\times 1.5$.

Fig. 9. Collarothyris canaliculata trapezoideus Modzalevskaya. 9a, ventral view; 9b, dorsal view; 9c, lateral view; 9d, anterior view; specimen 183/69; Kozhym River; sample 236/178; Belush'ya Stage; $\times 1.5$.

Figs. 10, 11. Howellella pseudogibbosa Nikiforova. 10, coquina; specimen 183/39; sample 236/6. 11 a, ventral view; 11 b, dorsal view; specimen 183/69; sample 236/8. Both from the Kozhym River; Belush'ya Stage; $\times 1.5$.

Fig. 12. Collarothyris canaliculata (Wenjukow). 12a, dorsal view; $12 \mathrm{~b}$, ventral view; specimen 183/167; Kozhym River; sample 236/261; Karpov Stage; $\times 1.5$. 

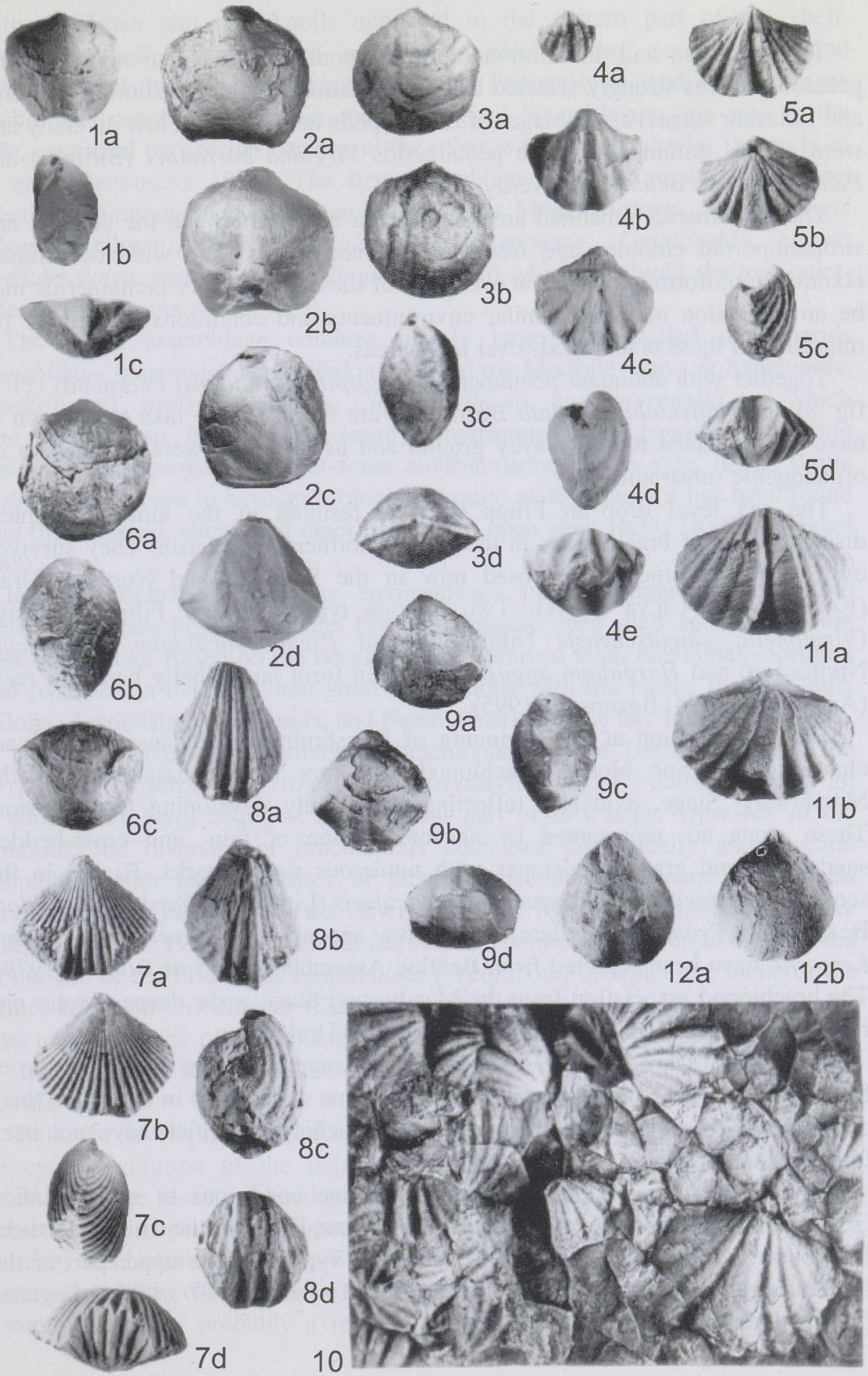


\section{PALAEOECOLOGY}

The evolution and distribution of brachiopods in the Timan-northern Ural palaeobasin was strongly affected by sedimentation. The early_Silurian (Yarenej and Lolashor stages) assemblages of brachiopods had relatively low diversity and were mainly dominated by the pentamerids Virgiana barrandei (Billings) and Pentamerus aff. oblongus Sowerby.

The pentamerids inhabited areas of the sea bottom between the tabulate and stromatoporoid colonies and frequently formed banks. The wide occurrence, taxonomic uniformity, and slow evolution of these Llandovery pentamerids may be an indication of rather similar environments and conditions favourable for migration of these brachiopods over large areas.

Together with abundant pentamerids, Zygospiraella duboisi (Verneuil) (Pl. I, fig. 8) and Nalivkinia costulata Beznosova are found. These taxa are known to have been adapted to soft clayey ground and usually they were attached to an organogenic substratum.

The sea level drop in Filipp"el' time resulted in the almost complete disappearance of brachiopods in the Timan-northern Ural basin. They survived only in reefal structures exposed now in the Subpolar and Northern Urals (Kozhym and Un'ya rivers). Two species typical of the Filipp"el' Stage (Virgianella vaigatschensis Nikiforova and Pseudoconchidium kozhimicum Nikiforova) and Harpidium angustum Poulsen form large shelly banks in reefs (Antoshkina 1994; Beznosova 1995).

The transgression at the beginning of Marshrutnyj time caused significant changes in marine biotas. Brachiopods are rare in the basal part of the Marshrutnyj Stage, evidently reflecting the rapidly developing transgression. These strata are represented by an intercalation of thin- and cross-bedded sandstones and gravel-sandstones with numerous ripple marks. Higher in the sequence, Leptaena? sp., Atrypa ex gr. reticularis (Linnaeus), Fardenia flabellata Beznosova, Protatrypa inflata Beznosova appear. The genera Atrypa and Leptaena have been reported from Benthic Assemblages 3-5 of Boucot (1979). The brachiopod association from the Marshrutnyj Stage is the deepest-water one recognized in the Silurian of the Timan-northern Ural region.

In early Ust'Durnayu time, in conditions of regression, the sedimentation of fine silt dominated, and stromatolite banks became widespread in the basin. Such conditions were evidently unfavourable for brachiopods which have not been found in these strata.

In late Ust'Durnayu time, the normal marine conditions of sedimentation (similar to those of Marshrutnyj time) were re-established in the Timan-northern Ural basin, but the brachiopods were still rare. Typical of the upper part of the Ust'Durnayu Stage are Spirinella nordensis (Ljashenko), Atrypoidea linguata (Buch), and Hyattidina sp. (Beznosova 1994). 
In Padimejtyvis and Sizim times, terrigenous material was deposited in the southern Timan and reef knolls appeared in the eastern part of the shelf. Restricted shelf environments negatively affected the development and distribution of benthic assemblages. In the Padimejtyvis and Sizim stages brachiopods can be divided into two ecological assemblages: one was in the main, restricted part of the basin, and the other was connected with the reefs in the east (Beznosova 1998). The first assemblage includes small smooth and ribbed brachiopods such as Greenfieldia uberis Modzalevskaya, Didymothyris didyma (Dalman), Eoreticularia annae Beznosova, Lenatoechia clauda Modzalevskaya, and Atrypoidea linguata (Buch) which inhabited shallow quietwater environments.

The reefal assemblage contains mainly large thick-walled pentamerids (Conchidium novosemelicum Nalivkin, C. tegularis Modzalevskaya \& Sapelnikov, Brooksina aff. streisi Sapelnikov, Capelliniella sp., and Vagranella sp.) which were adapted to life in high-energy environments. Didymothyris didyma (Dalman), characteristic of quiet-water environments, is very rare. In the Baltic D. didyma is known to have an ecologically quite wide range - it has been found from the lagoonal, shoal, and inner part of the open shelf facies (Kaljo \& Rubel 1982).

In early Belush'ya time the environments in the Timan-northern Ural palaeobasin were highly variable. For brachiopods, open shelf conditions were most favourable. Based on the occurrence of common taxa, the Timan-northern Ural palaeobasin evidently had good connections with the basins in the Baltic, Podolia, Arctic islands of Russia, and North America in the late Ludfordian.

The most diverse and numerous brachiopods in the Belush'ya Stage are Atrypoidea, Collarothyris, Howellella, Hemitoechia, and Pseudohomeospira all of which may form coquinas in the basal part of this stage. Upwards in the sequence, the diversity of brachiopods decreases dramatically and a coral assemblage with large colonies of tabulates becomes dominant. Grebenella parvula (Tshernyshew \& Yakovlew) (Pl. IV, fig. 4), Atrypoidea insigne (Nikiforova) (Pl. IV, fig. 3), and Collarothyris canaliculata (Wenjukow) existed till the end of the Pridoli. C. canaliculata (Wenjukow) occupied the niche of the extinct Didymothyris didyma (Dalman), and this species can be considered the most tolerant in the rapidly changing environmental conditions at the beginning of Belush'ya and Karpov times. Also, in this part of the section, Grebenella parvula appears.

Thus, the development and distribution of brachiopods depended heavily upon the cyclic evolution of the palaeobasin. The changes in the succession of brachiopods are closely related to the regressive and transgressive stages in the carbonate sedimentation. The pentamerid assemblages in the early Llandovery (Yarenej and Lolashor stages) are direct descendants of the late Ordovician ones (Beznosova 1995). The common feature of both of them is the predominance of cosmopolitan taxa, probably a result of a global transgression. Endemic taxa 
dominated in Filipp"el', Marshrutnyj, and Ust'Durnayu times. Large shallowwater areas with relatively flat bottoms in the Timan-northern Ural palaeobasin caused wide occurrence of low-diversity brachiopod assemblages. All the Silurian brachiopod assemblages belong to Benthic Assemblage 2 or 3 of Boucot (1979) apart from the assemblage in the Marshrutnyj Stage which represents Benthic Assemblages 3-5.

An important factor which hindered the brachiopod distribution in the Llandovery (Filipp"el' Stage) and in Padimejtyvis and Sizim times is the wide occurrence of cyanobacterial associations forming stromatolitic mats and the development of reefs (Antoshkina 1994).

\section{CONCLUSIONS}

Ten brachiopod zones - Virgiana barrandei-Zygospiraella duboisi, Pentamerus aff. oblongus, Pseudoconchidium kozhimicum-Virgianella vaigatschensis, Fardenia flabellata, Spirinella nordensis, Greenfieldia uberis, Didymothyris didyma, Conchidium novosemelicum, Atrypoidea scheiiHowellella pseudogibbosa, and Atrypoidea insigne-Grebenella parvula - have been described in the Silurian strata in the Timan-northern Ural region. In most cases, the zonal boundaries are defined by the first appearance of the zonal taxon and are characterized by sharp changes in the brachiopod faunas. Late Ashgill, Llandovery, Ludlow, and Přidoli brachiopod assemblages are widespread and can be recognized in other regions too. Wenlock taxa are represented mainly by endemic forms.

\section{ACKNOWLEDGEMENTS}

The manuscript was much improved following the comments of the reviewer L. R. M. Cocks and an anonymous referee.

\section{REFERENCES}

Antoshkina, A. I. 1994. Rify v paleozoe Pechorskogo Urala. Nauka, St. Petersburg (in Russian).

Antoshkina, A. I. 2000. The Silurian of the Timan-northern Ural region. Proc. Estonian Acad. Sci. Geol., 49, 69-84.

Antoshkina, A. I. \& Beznosova, T. M. 1988. New data on the stratigraphy of the Wenlock deposits of the Bol'shaya Zemlya Tundra. Byull. MOIP, Otd. Geol., 63, 32-39 (in Russian).

Antoshkina, A. I. \& Beznosova, T. M. 1999. The Llandovery-Wenlock boundary in the Urals. In Geologiya i mineral'nye resursy evropejskogo severo-vostoka Rossii: novye rezul'taty $i$ novye perspektivy. Materialy XIII Geologicheskogo s"ezda Respubliki Komi, Vol. II (Yushkin, N. P., ed.), pp. 187-189. Inst. geol. Komi nauch. tsentra UrO RAN, Syktyvkar (in Russian). 
Antsygin, N. Ya., Popov, B. A. \& Chuvashov, B. I. (eds.). 1993. Stratigraficheskie skhemy Urala. IGiG UNTs RAN, Ekaterinburg (in Russian).

Beznosova, T. M. 1989a. Upper Ordovician and lower Silurian zonal subdivisions in the northern part of the European USSR (on the basis of brachiopods). In Novye dannye po rannim $i$ srednepaleozojskim brakhiopodam SSSR (Puchkov, V. N., ed.), pp. 5-9. UrO AN SSSR, Sverdlovsk (in Russian).

Beznosova, T. M. 1989b. Zonal subdivision of Upper Ordovician and lower Silurian deposits in the northern part of the European USSR based on brachiopods. In Paleontologicheskoe obosnovanie i korrelyatsiya fanerozojskikh otlozhenij Evropejskogo severa SSSR. Tr. In-ta geologii Komi nauch. tsentra UrO AN SSSR, 71, 5-16 (in Russian).

Beznosova, T. M. 1994. Biostratigrafiya i brakhiopody silura Evropejskogo severo-vostoka Rossii. Nauka, St. Petersburg (in Russian).

Beznosova, T. M. 1995. Late Ashgillian brachiopod communities of the Subpolar Urals. In Ordovician Odyssey: Short Papers for the Seventh International Symposium on the Ordovician System, Las Vegas, Nevada, USA (Cooper, J. D., Droser, M. L. \& Finney, S. C., eds.), pp. 471-472. Pacific Section Soc. for Sedim. Geol. (SEPM), Fullerton, California.

Beznosova, T. M. 1998. Main Ludlow brachiopod communities on the western slope of the Urals. In Syktyvkarskij paleontologicheskij sbornik. Tr. In-ta geol. Komi nauch. tsentra UrO RAN, 3, 53-59 (in Russian).

Boucot, A. J. 1979. Evolution and Extinction Rate Controls. Elsevier, Amsterdam.

Brejvel', M. G., Papulov, G. N. \& Khodalevich, A. N. (eds.). 1980 . Unifitsirovannye $i$ korrelyatsionnye skhemy Urala: Materialy i resheniya III Ural'skogo mezhvedomstvennogo stratigraficheskogo soveshchaniya. IGiG UNTs AN SSSR, Sverdlovsk (in Russian).

Kaljo, D. L. \& Rubel, M. P. 1982. Relations of brachiopod communities to facial zones (Silurian, East Baltic). In Communities and Biozones in the Baltic Silurian (Kaljo, D. \& Klaamann, E., eds.), pp. 11-34. Valgus, Tallinn (in Russian).

Männik, P., Antoshkina, A. I. \& Beznosova, T. M. 2000. The Llandovery-Wenlock boundary in the Russian Arctic. Proc. Estonian Acad. Sci., Geol., 49, 104-111.

Mel'nikov, S. V. 1984. Correlation of Upper Ordovician-lower Llandovery oil- and gas-bearing deposits of the Timan-Pechora Province on conodonts. In Geologiya $i$ prognoz neftegazonosnosti Timano-Pechorskoj provintsii (Bogatskij, V. I., ed.), pp. 16-23. VNIGRI, Leningrad (in Russian).

Melnikov, S. V. \& Zhemchugova, V. A. 2000. Lower Silurian stratigraphy of the Timan-northern Ural region and eustatic fluctuation. Proc. Estonian Acad. Sci. Geol., 49, 85-103.

Modzalevskaya, T. L. 1974. Late Silurian and early Devonian brachiopods from the Subpolar Urals. Paleontol. Zh., 2, 68-83 (in Russian).

Modzalevskaya, T. L. 1979. About taxonomy of Palaeozoic athyridids. Paleontol. Zh., 2, 48-63 (in Russian).

Modzalevskaya, T. L. 1980a. Some stratigraphical problems of Silurian deposits in the Bol'shaya Zemlya Tundra. Ezhegodnik VPO, 23, 229-304 (in Russian).

Modzalevskaya, T. L. 1980b. Silurian and Lower Devonian brachiopods from Dolgij Island and their stratigraphical importance. In Silur i nizhnij devon o-va Dolgogo (Sapel'nikov, V. P., ed.), pp. 82-106. UNTs AN SSSR, Sverdlovsk (in Russian).

Modzalevskaya, T. L. 1985. Brachiopody silura i rannego devona Evropejskoj chasti SSSR: Otryad Athyridida. Nauka, Moscow (in Russian).

Modzalevskaya, T. L. \& Beznosova, T. M. 1992. Some Silurian Spiriferidae from the Pechora Urals and Soviet Arctic islands. In Fanerozoj evropejskogo severa Rossii. Tr. In-ta geol. Komi nauch. tsentra UrO RAN, 75, 4-16 (in Russian).

Modzalevskaya, T. L. \& Märss, T. 1991. On the age of the Lower boundary of the Greben' Regional Stàge of the Urals. Proc. Estonian Acad. Sci. Geol., 40, 100-103. 
Modzalevskaya, T. L. \& Wenzel, B. 1999. Biostratigraphy and geochemistry of Upper Silurian brachiopods from the Timan-Pechora region (Russia). Acta Geol. Polonica, 49, 145-157.

Pershina, A. I. 1971. Biostratigrafiya silurijskikh $i$ devonskikh otlozhenij Pechorskogo Urala. Nauka, Leningrad (in Russian).

Sapel'nikov, V. P. \& Beznosova, T. M. 1980. Some Ashgillian and Silurian zonal pentamerids from the Pechora Urals. In Novye materialy po pentameridam Urala (Malakhova, V. P., ed.), pp. 3-24. UNTs AN SSSR, Sverdlovsk (in Russian).

Tsyganko, V.S. \& Chermnykh, V. A. (eds.). 1983. Opornye razrezy pogranichnykh otlozhenij silura i devona Pripolyarnogo Urala. Syktyvkar (in Russian).

Tsyganko, V. S. \& Chermnykh, V. A. (eds.). 1987. Opornye razrezy ordovika i silura Pripolyarnogo Urala. Inst. geol. Komi filiala Akad. nauk SSSR, Syktyvkar (in Russian).

\title{
SILURI BRAHHIOPOODID TIMAANI-UURALI PÕHJAOSA REGIOONIS: TSONAALSUS JA PALEOÖKOLOOGIA
}

\section{Tatjana BEZNOSSOVA}

Timaani-Uurali põhjaosa regioonis on silur esindatud peamiselt mitmesuguste karbonaatsete (läbilõike alumises osas üldjuhul tugevalt dolomiidistunud) ja terrigeensete setetega. Settimistingimused varieerusid siluri basseinis kaldalähedastest madalaveelistest (supra- ja sublitoraal) kuni avamereliste süvaveelisteni (mandrinõlv, ookeaniline).

Brahhiopoodid on uuritud regiooni bentilises faunas üks rikkalikumalt esindatud rühmi. Nad on olulise tähtsusega Timaani-Uurali põhjaosa regiooni siluri läbilõigete liigestamisel ja korreleerimisel samavanuste kihtidega Baltikumis, Podoolias ja Venemaa arktilistes piirkondades.

\section{СИЛУРИЙСКИЕ БРАХИОПОДЫ ТИМАНО-СЕВЕРОУРАЛЬСКОГО РЕГИОНА: ЗОНАЛЬНОСТЬ И ПАЛЕОЭКОЛОГИЯ}

\author{
Татьяна М. БЕЗНОСОВА
}

В Тимано-Североуральском регионе силур представлен главным образом различными известняками (как правило, сильно доломитизированными в нижней части разреза) и вапорятами. Условия осадконакопления в бассейне изменялись от прибрежных супралиторальных и сублиторальных до склоновых и бассейновых.

Брахиоподы являются одной из наиболее широко представленных групп бентосной фауны и имеют важное значение для региональной стратиграфии и корреляции силурийских отложений Тимано-Североуральского региона с одновозрастными отложениями Балтики, Подолии и Арктических регионов России. 